\title{
Editorial
}

\section{Cultural Entrepreneurship}

Place Branding and Public Diplomacy (2013) 9, 141-142. doi:10.1057/pb.2013.22

Regions are becoming increasingly interdependent, not only economically but also socially and environmentally. In today's globalizing society, they are more reliant on inter-regional flows of trade, tourism, labor and resources. Pervasive information and communications technology, intertwined with the global dispersion of supply chains and networks, is inducing a sizeable structural transformation. As a result, patterns of interaction between regions are showing a dramatic center-of-gravity shift in terms of production and consumption. These changes, in turn, constitute intimidating challenges for the analyzing and managing regions, particularly from the perspective of cultural production. Although technology may be the key driving force, the responses of businesses and regions to these transformations depend on the economic, political and social arrangements in place within organizations and society. This special issue of Place Branding and Public Diplomacy presents papers from the Cultural Entrepreneurship Conference (CEC) held in Pori, Finland in December 2012. The overarching theme is a networked cultural heritage and its influence on regional prosperity, especially from the perspective of place branding. The six papers in question suggest alternative avenues for considering how new patterns of activities and relationships, and new forms of networking between regions in tandem with cultural production, can enhance competitiveness.

The first two papers in this special issue focus on networks and stakeholder cooperation in a rural context. The first of these, entitled The role of artists in place branding: a case study and written by Tuula
Mittilä and Tanja Lepistö, emphasizes the pivotal role of rural tourism in keeping the countryside alive in the face of cultural and technological change within an urbanized world. The authors studied the role of one stakeholder group, namely, artists, in the context of the construction of the identity of a place. As they note, in the future these direct and indirect roles should be better taken into consideration in the process of identity construction.

The focus in the second paper, entitled Challenges in joint place branding in rural regions and written by Maarit Vuorinen and Marita Vos, is on cooperation between the various stakeholders involved and on the salient features of rural regions that are used in the place-branding process. The fundamental question the authors pose concerns how to build long-term commitment among a group of key stakeholders. As they note, there are many sources of information on place branding in large cities, but rural regions have received little attention. They investigated the process in three rural regions in Finland through focus-group interviews. The authors conclude from their findings that the significance of the landscape is especially high for place branding in rural areas.

The next three papers discuss city branding from a cultural perspective. The first of these, entitled The relevance of cultural production - Pori Jazz - in boosting place brand equity and written by Arja Lemmetyinen, Frank Go and Mervi Luonila, uses a case-study design to unpack the cultural production that occurs in relation to the Pori Jazz Festival in Finland. This case provides an 
insight into what happens when the aspirations embedded within the identity of Pori, a relatively small community, interact with the realities of international marketing decisions. The purpose of the paper is to examine, from a brand-equity perspective, the impact of the context on the content of the Pori Jazz Festival in relation to the city and the audiences. The methodologically multi-layered content analysis supports the image transfer between the event and the host city. However, the authors call for more research in order to identify the networks the festival organization is managing.

The second paper, entitled One person can make a difference - although branding a place is not a one-man show and written by Ulla Hakala and Sevgi A. Öztürk, discusses the elements of branding a city, highlighting the role of enterprising, visionary people and the importance of their commitment to the process. The purpose is to explore the role of individuals and their visioning in place branding. According to the authors, even one person can make a difference, whether in initiating the branding process or in re-positioning the city. Their claim is supported by two case examples: Vernon in California and Eskişehir in Turkey.

Third, The role of gastronomic brands in tourist destination promotion (the case of St. Petersburg), written by Valery Gordin and Julia Trabskaya, focuses on a significant component of the attractiveness of a tourist destination, namely, territorial gastronomic branding. The authors discuss possible ways of building gastronomic brands in multicultural cosmopolitan cities in which authentic brands are extensively blurred. The research focuses specifically on St. Petersburg, which is a prototypical multicultural city lacking a pure 'food basis' on which to form a territorial gastronomic brand.

Finally, Kati Suomi, Arja Lemmetyinen and Frank Go's paper, entitled The tension between a distinct brand identity and harmonisation - findings from Finnish higher education, focuses on the need for a distinct brand identity, and for harmonization in a copycat environment. Its contribution to the discussion on brand identity lies in identifying place as a new component in the higher-education context.

With this volume we hope to encourage further discussion on the above issues. We would like to thank the editors of Place Branding and Public Diplomacy, Nicholas J. Cull, Robert Govers and Liz Holwell, for providing us with a platform for presenting the studies in the current special issue.

Frank Go

Rotterdam School of Management, Rotterdam, The Netherlands

Ulla Hakala

University of Turku, Turku, Finland

Arja Lemmetyinen University of Turku, Pori Unit, Finland 